\title{
Nutritional Evaluation of Cookies Enriched with Bottle Gourd (Lagenaria Siceraria I.) Powder
}

\author{
Murlidhar Ingle ${ }^{1}$, and Suresh Thorat ${ }^{2}$
}

\begin{abstract}
Bottle gourd (Lagenaria siceraria L.) is used in traditional Indian medicine and is well known for their antioxidant, anti-stress, analgesic, anti-inflammatory, cardio protective, cardio tonic, diuretic, aphrodisiac, alternative purgative and cooling properties. The study was conducted to improve the nutritional qualities of cookies with addition of different levels of bottle gourd powder. Cookies were prepared with different levels of bottle gourd powder $(0,5,7,10,15$ and $20 \%)$ and examined for its physical and chemical composition. The proximate composition of cookies enriched with bottle gourd powder indicated that protein was increased from 9.93 to $13.15 \%$, crude fibre $0.9-2.75 \%$ and spread ratio 3.31-4.20. The incorporation of bottle gourd powder in cookies lowered the lightness $\left(\mathrm{L}^{*}\right)$ and yellowness (b*) but increased redness $\left(a^{*}\right)$ of cookies. The hardness of the cookies was increased with increasing the level of bottle gourd powder. It was concluded that the cookies prepared with addition of 7 to $10 \%$ bottle gourd powder were more acceptable as compared to others.

Keywords: Cookies, bottle gourd, protein, crude fiber, color, hardness.
\end{abstract}

\section{INTRODUCTION}

Bottle gourd (Lagenaria siceraria L.) is an important vegetable crop of tropical and subtropical regions of the world belonging to family Cucurbitaceae. The fruit finds its medicinal value in traditional Indian medicine and has been used as cardiotonic, aphrodisiac, general tonic, hepatoprotective, analgesic, anti-inflammatory, expectorant and diuretic [1]. Further, antihepatotoxic activity of fruit pulp [2-3]. Phytochemical screening on L. siceraria fruit has revealed the presence of fucosterol and compesterols [4], flavonoids, cucurbitacins, saponins, polyphenolics, triterpenoids [5]. Various extracts of fruit of Lagenaria siceraria were found to have anti-inflammatory, analgesic, hepatoprotective, anti-hyperlipidemic, diuretic and antibacterial activities [6].

Apart from above the bottle gourd also contents $1.6 \%$ choline on a dry weight basis; a precursor to acetylcholine, a chemical used to transfer nerve impulses and hence, it is believed to have neurological effects. Bottle gourd contains cucurbitacins, polyphenols and two sterols namely; campesterol and sitosterol [1]. Bottle gourd is well known for their immunomodulatory, hepatoprotective, antioxidant, anti-stress, adaptogenic, analgesic, anti-

1 Dept. of Food Science and Technology, Post Graduate Institute, Mahatma Phule Krishi Vidyapeeth, Rahuri. Dist. Ahmednagar (Maharashtra) 413722

2 Dept. of Food Science and Technology, Post Graduate Institute, Mahatma Phule Krishi Vidyapeeth, Rahuri. Dist. Ahmednagar (Maharashtra) 413722 
inflammatory, cardio protective, cardio tonic, antihyperlipidemic, diuretic, aphrodisiac, alternative purgative, antidote to certain poisons and cooling properties [2],[7-8].

The bakery industry is one of the largest organized food industries all over the world and in particular biscuits and cookies are one of the most popular products because of their convenience, ready to eat nature, and long shelf life [9]. Cookies are widely consumed baked products which can be served from breakfast to bedtime. Cookies are appreciated for their taste, aroma, convenience, and long shelf stability due to low moisture content. Recently, increasing consumer demand for healthier foods has triggered the development of cookies made with natural ingredients exhibiting functional properties and providing specific health benefits beyond those to be gained from traditional nutrients [10].

Foods with high nutritional value are in great demand for proper functioning of body systems and potential health benefits. As a result, value-added foods or functional foods with higher level of dietary fiber and antioxidant have been developed, especially in bakery products such as cookies. The incorporation of composite flour into traditional wheat based food products provided additional nutrients from non-wheat material and improved the nutritional value of the products [11].

The utilization of bottle gourd powder with wheat flour in bakery products have not been studied extensively. Therefore, the research was designed to evaluate the effect of substitution of wheat flour with different levels of bottle gourd powder on the physicochemical and sensory properties of the cookies.

\section{MATERIALS AND METHODS}

\section{Materials}

Fresh green and well matured bottle gourds were obtained from the local market of Rahuri, Dist. Ahmednagar. The ingredients for cookies such as wheat flour, fat, sugar, ammonium bicarbonate and sodium bi carbonate were used from, pilot bakery unit of the department of food science and technology, MPKV Rahuri.

\section{Processing of bottle gourd powder}

Fresh bottle gourds were washed, peeled and reduced to size (1-3 mm) using sharp knife. The slices were blanched and dried in tray dryer at $60-65{ }^{\circ} \mathrm{C}$ for about $7-8 \mathrm{~h}$. The dried bottle gourd slices were subjected to grinding in grinder. Then ground material was passed through 60 mesh sieve and packed in HDPE bags, sealed and stored for further use.

\section{Cookies preparation}

Bottle gourd cookies were prepared by substituting refined wheat flour with bottle gourd powder (BGP). Various blends were prepared using refined wheat flour and bottle gourd powder in the ratio of $100: 0 ; 95: 5 ; 93: 7 ; 90: 10 ; 85: 15 ; 80: 20$. The cookies were prepared using procedure as suggested in Fig. 1. 


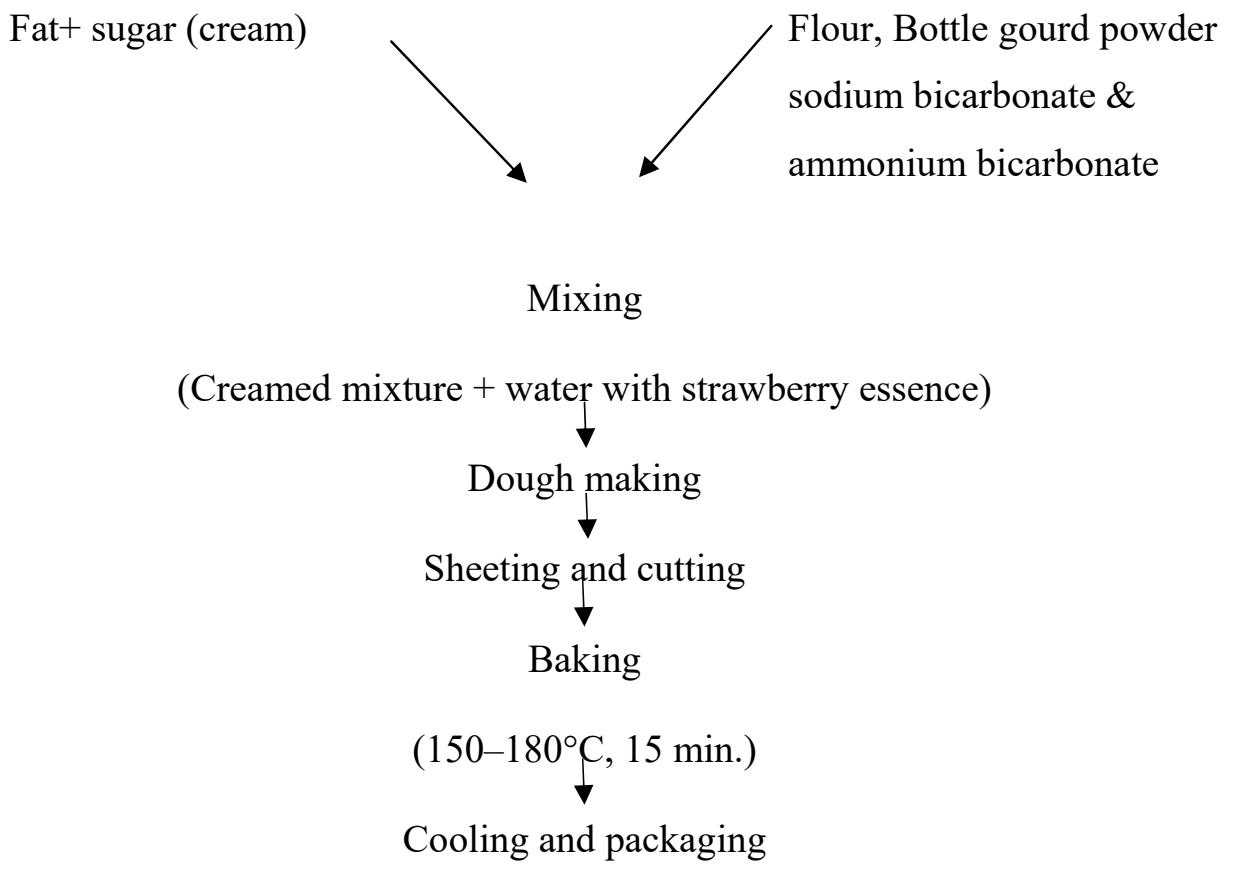

Fig.1. Method for preparation of cookies

\section{Physical characteristics}

The physical characteristics of cookies such as diameter, thickness, spread ratio were measured as described in the A.A.C.C. (2000) methods [12].

\section{Sensory evaluation of cookies:}

The cookies were evaluated by panel of 10 semi-trained judges. Nine-point Hedonic Scale and Score Card method were used for evaluation of sensory characteristics of different cookies [13].

\section{Texture measurement}

Texture of cookies was evaluated by a universal texture analyser (AG X, Shimadzu Japan, capacity $2500 \mathrm{~N}$ [14].

\section{Colour measurement}

Surface color of cookies was determined by measuring tristimulus L (brightness), a (redness), $\mathrm{b}$ (yellowness) and Hue $(\mathrm{H})$ values with a colorimeter (CIELAB) [15].

\section{Proximate composition}

Proximate analysis of cookies for moisture, crude protein, crude fat and ash content were determined according to the AOAC (2000) standard methods [16]. The carbohydrate content was determined by subtracting the sum of the values (per $100 \mathrm{~g}$ ) for moisture, total ash, crude fat, crude fibre and crude protein from hundred. The calorific value (Kcal per 100g) of sample was calculated by summing up the product of multiplication of per cent crude protein, crude fat and carbohydrate present in the sample by 4,9 , and 4 , respectively [17]. 
9. Statistical analysis: All results were statistically analysed by using CRD [18].

\section{RESULTS AND DISCUSSION}

\section{Proximate composition}

Moisture content of control was $2.57 \%$ and that of cookies containing bottle gourd powder increased from 2.97 to $5.10 \%$. Crude protein content of control was $10.19 \%$ and that of cookies containing incremental levels of bottle gourd powder increased from 9.93 to $13.15 \%$ (Table 1). Ash content of the cookies containing incremental levels of bottle gourd powder was increased from 1.44 to $2.16 \%$ which was significantly higher than that of control. Crude fiber content of cookies was significantly increased from 0.95 to $2.75 \%$ with addition of bottle gourd powder up to $20 \%$. Crude fat and carbohydrates contents were decreased from 23.42 to $22.22 \%, 62.98$ to 57.37 respectively with addition of bottle gourd powder. The difference in moisture content between samples might be due to the high fiber content in bottle gourd. More hydroxyl groups of cellulose in fiber were able to bind with free water molecules through hydrogen bonding and thus resulting in greater water holding capacity [19]. Results showed that higher amount of bottle gourd powder substituted into formulation resulted in increased protein and fiber content in cookies in accordance with the findings of [20-21].

It is revealed that with increased level of bottle gourd powder in cookies, there was increase in calcium, phosphorous, iron and zinc content of cookies with decrease in calorific value of cookies. The calcium content of cookies increased from 30.12 to 38.47 , phosphorous content increased from 151 to 162 , iron content was increased from 1.13 to 3.24 and zinc content from 0.31 to 0.77 with increased level of bottle gourd powder in cookies. Results showed that higher amount of bottle gourd powder substituted into formulation resulted in increased minerals content in cookies in accordance with the findings of [20] and [10].

Table 1: Chemical composition of bottle gourd powder incorporated cookies

\begin{tabular}{|c|c|c|c|c|c|c|}
\hline Treatments* & $\begin{array}{c}\text { Moisture } \\
\mathbf{( \% )}\end{array}$ & $\begin{array}{c}\text { Protein } \\
\mathbf{( \% )}\end{array}$ & $\begin{array}{c}\text { Fat } \\
\mathbf{( \% )}\end{array}$ & $\begin{array}{c}\text { Carbohydrates } \\
\mathbf{( \% )}\end{array}$ & $\begin{array}{c}\text { Ash } \\
\mathbf{( \% )}\end{array}$ & $\begin{array}{c}\text { Crude } \\
\text { fiber } \\
\mathbf{( \% )}\end{array}$ \\
\hline $\mathrm{T}_{0}$ & 2.57 & 10.19 & 23.42 & 62.98 & 0.84 & 0.95 \\
\hline $\mathrm{T}_{1}$ & 2.97 & 9.93 & 23.14 & 62.52 & 1.44 & 0.99 \\
\hline $\mathrm{T}_{2}$ & 3.41 & 10.76 & 22.78 & 61.44 & 1.61 & 2.25 \\
\hline $\mathrm{T}_{3}$ & 3.90 & 11.07 & 22.44 & 60.97 & 1.62 & 2.49 \\
\hline $\mathrm{T}_{4}$ & 4.48 & 12.36 & 22.27 & 59.09 & 1.80 & 2.43 \\
\hline $\mathrm{T}_{5}$ & 5.10 & 13.15 & 22.22 & 57.37 & 2.16 & 2.75 \\
\hline $\mathrm{SE} \pm$ & 0.14 & 0.16 & 0.05 & 0.03 & 0.03 & 0.04 \\
\hline $\mathrm{CD} @ 5 \%$ & 0.43 & 0.48 & 0.13 & 0.08 & 0.10 & 0.13 \\
\hline
\end{tabular}

* Indicates proportion of wheat flour: bottle gourd powder 
$\mathrm{T}_{0}(100: 0), \mathrm{T}_{1}(95: 5), \mathrm{T}_{2}(93: 7), \mathrm{T}_{3}(90: 10), \mathrm{T}_{4}(85: 15)$ and $\mathrm{T}_{5}(80: 20)$.

Table 2. Effects of bottle gourd powder on micro-nutrient of cookies

\begin{tabular}{|c|c|c|c|c|c|}
\hline Treatments* & $\begin{array}{c}\text { Calcium } \\
\mathbf{m g} / \mathbf{1 0 0 g}\end{array}$ & $\begin{array}{c}\text { Phosphorous } \\
\mathbf{m g} / \mathbf{1 0 0 g}\end{array}$ & $\begin{array}{c}\text { Iron } \\
\mathbf{m g} / \mathbf{1 0 0 g}\end{array}$ & $\begin{array}{c}\text { Zinc } \\
\mathbf{m g} / \mathbf{1 0 0 g}\end{array}$ & $\begin{array}{c}\text { Calorific } \\
\text { value (kcal) }\end{array}$ \\
\hline $\mathrm{T}_{0}$ & 30.12 & 151 & 1.13 & 0.77 & 510.77 \\
\hline $\mathrm{T}_{1}$ & 32.21 & 153 & 1.81 & 0.31 & 505.30 \\
\hline $\mathrm{T}_{2}$ & 33.06 & 155 & 2.62 & 0.35 & 501.04 \\
\hline $\mathrm{T}_{3}$ & 35.31 & 157 & 2.04 & 0.38 & 497.32 \\
\hline $\mathrm{T}_{4}$ & 36.74 & 160 & 3.15 & 0.42 & 493.37 \\
\hline $\mathrm{T}_{5}$ & 38.47 & 162 & 3.24 & 0.51 & 489.11 \\
\hline $\mathbf{S E} \pm$ & 0.715 & 1.354 & 0.063 & 0.008 & 0.204 \\
\hline CD $\mathbf{0}$ 5\% & 2.124 & 4.024 & 0.187 & 0.023 & 0.606 \\
\hline
\end{tabular}

* as suggested in Table 1.

\section{Texture analysis of cookies}

It was revealed that the hardness of cookies was found to increase with addition of bottle gourd powder (Table 3). The increased hardness may be attributed to dilution of wheat proteins with bottle gourd proteins and fiber. There was positive correlation of fiber and protein contents with the hardness value of cookies made [22]. The increase in cookies hardness was observed with increased fiber substitution [23]. The dough prepared from highabsorption flour resulted in hard texture [24]. Therefore, high fiber content in bottle gourd powder was evident to produce cookies with hard texture.

Table 3: Effect of different levels of bottle gourd powder on textural characteristics of cookies

\begin{tabular}{|c|c|c|c|c|}
\hline Treatments* & Force Max (N) & $\begin{array}{c}\text { Break Force } \\
\text { Sensitivity } \\
(\mathbf{N})\end{array}$ & $\begin{array}{c}\text { Max } \\
\text { Displacement } \\
\text { Force (N) }\end{array}$ & Energy (J) \\
\hline $\mathrm{T}_{0}$ & 57.88 & 55.44 & 20.49 & 0.05 \\
\hline $\mathrm{T}_{1}$ & 50.62 & 50.65 & 8.32 & 0.04 \\
\hline $\mathrm{T}_{2}$ & 55.64 & 55.55 & 11.52 & 0.06 \\
\hline $\mathrm{T}_{3}$ & 63.64 & 63.43 & 15.48 & 0.07 \\
\hline $\mathrm{T}_{4}$ & 69.64 & 69.33 & 20.58 & 0.07 \\
\hline
\end{tabular}




\begin{tabular}{|c|c|c|c|c|}
\hline $\mathrm{T}_{5}$ & 79.29 & 79.41 & 39.38 & 0.09 \\
\hline $\mathrm{SE} \pm$ & 0.12 & 0.11 & 0.11 & 0.00 \\
\hline $\mathrm{CD} @ 5 \%$ & 0.35 & 0.32 & 0.34 & 0.01 \\
\hline
\end{tabular}

* as suggested in Table 1.

\section{Physical characteristics of cookies}

There were no significant differences in the diameter and thickness of the cookies between those containing up to $5.0 \%$ bottle gourd powder and the control (Table 4). However, significant differences were found with higher levels of bottle gourd powder. Larger diameter and lower thickness values were observed as the level of bottle gourd powder substitution increased. The incorporation of bottle gourd powder affected cookie expansion by lowering gas retention compared to control. The spread ratio of cookies made with bottle gourd powder was significantly lower than that of control. [25] reported that cookies made with yam powder exhibited a reduction in size and thickness as the content of yam powder increased. It was reported that the spread ratio of cookies prepared with bamboo leaf powder decreased with increased amount of bamboo leaves powder [26]. [27] also reported that the addition of sea tangle powder lowered the spread ratio of cookies. The cookies spread ratio or diameter is used as an indicator of cookie quality and cookies with larger spread or diameter were considered more desirable [28].

Table 4: Physical parameters of bottle gourd powder incorporated cookies

\begin{tabular}{|c|c|c|c|c|}
\hline Treatments* & $\begin{array}{c}\text { Weight } \\
(\mathbf{g})\end{array}$ & $\begin{array}{c}\text { Diameter } \\
\mathbf{( m m})\end{array}$ & $\begin{array}{c}\text { Thickness } \\
(\mathbf{m m})\end{array}$ & $\begin{array}{c}\text { Spread } \\
\text { ratio }\end{array}$ \\
\hline $\mathrm{T}_{0}$ & 9.48 & 43.26 & 10.29 & 4.20 \\
\hline $\mathrm{T}_{1}$ & 9.45 & 43.15 & 12.51 & 3.99 \\
\hline $\mathrm{T}_{2}$ & 10.04 & 44.25 & 10.82 & 3.54 \\
\hline $\mathrm{T}_{3}$ & 10.28 & 44.65 & 12.45 & 3.59 \\
\hline $\mathrm{T}_{4}$ & 10.59 & 45.05 & 13.03 & 3.46 \\
\hline $\mathrm{T}_{5}$ & 10.82 & 46.58 & 14.09 & 3.31 \\
\hline $\mathrm{SE} \pm$ & 0.18 & 0.22 & 0.38 & 0.08 \\
\hline $\mathrm{CD} @ 5 \%$ & 0.53 & 0.65 & 1.13 & 0.24 \\
\hline
\end{tabular}

* as suggested in Table 1.

\section{Colour measurement}

The data presented in Table 5 illustrated that control cookies had significant difference in terms of L (Lightness), a (Redness), b (yellowness), C (chroma) and h (hue) values compared to all other cookies made by substitution with bottle gourd powder. The lightness value of control cookies was 68.78 and those of bottle gourd powder cookies decreased from 59.90 to 50.88 , indicating that lightness decreased with the reduction in the proportion of wheat flour 
because of the loss of white color of the flour. The redness value of control cookies was 4.677 and those of bottle gourd powder cookies was ranged $6.186 \sim 6.651$, showing more reddish color than control. The yellowness value of control cookies was 22.853 and cookies substituted with different levels of bottle gourd powder decreased from 19.832 to 15.2974, having more yellowish color than control. Hue refers to a term that describes the pure spectrum color without tint or shade. The increased level of substitution of bottle gourd powder significantly reduced the hue value.

[20,29] observed decreased lightness of cookies as the substitution level of fiber into formulation was elevated. Control cookies had significant difference in $b^{*}$ and $C^{*}$ values compared to other cookies. The differences in color could be due to uneven exposure of cookies' surface area to high baking temperature and colored compounds formed from chemical reactions such as caramelization and Maillard reaction [30]. Borrelli et al. (2003) reported that the reaction between protein and carbohydrate was responsible for the brown colour and organoleptic properties of bakery products [31].

Table 5: Effect of different levels of bottle gourd powder on color characteristics of cookies

\begin{tabular}{|c|c|c|c|c|c|}
\hline Treatments* & $\mathbf{L}^{*}$ & $\mathbf{a}^{*}$ & $\mathbf{b}^{*}$ & $\mathbf{C}^{*}$ & $\mathbf{H}^{*}$ \\
\hline $\mathrm{T}_{0}$ & 68.783 & 4.677 & 22.853 & 23.255 & 78.334 \\
\hline $\mathrm{T}_{1}$ & 59.905 & 6.404 & 19.832 & 20.923 & 78.083 \\
\hline $\mathrm{T}_{2}$ & 58.677 & 6.454 & 19.187 & 20.182 & 75.298 \\
\hline $\mathrm{T}_{3}$ & 57.262 & 6.675 & 19.131 & 20.103 & 70.814 \\
\hline $\mathrm{T}_{4}$ & 52.731 & 6.186 & 15.695 & 16.839 & 68.846 \\
\hline $\mathrm{T}_{5}$ & 50.876 & 6.651 & 15.297 & 16.484 & 66.686 \\
\hline $\mathrm{SE} \pm$ & 0.499 & 0.075 & 0.023 & 0.049 & 0.056 \\
\hline $\mathrm{CD} @ 5 \%$ & 1.481 & 0.222 & 0.067 & 0.146 & 0.168 \\
\hline
\end{tabular}

* as suggested in Table 1.

\section{Sensory evaluation:}

The treatment $T_{2}$ obtained higher average score for color and appearance (7.54) with minimum score by treatment $\mathrm{T}_{5}(5.60)$. The treatment $\mathrm{T}_{2}$ obtained highest score for texture and grain (7.76), flavor (8.13), taste (7.98) and overall acceptability (7.83) as compared to control $\mathrm{T}_{0}$ treatment (Table 6). The surface colour was darker as the bottle gourd powder level increased. Therefore, replacing up to $7-10 \%$ wheat flour with bottle gourd powder would not result in significant differences in the acceptability of cookies.

Table 6: Effect of different levels of bottle gourd powder on sensory characteristics of cookies

\begin{tabular}{|l|l|l|l|l|l|}
\hline Treatments* & Colour and & Texture & Flavour & Taste & Overall \\
\hline
\end{tabular}




\begin{tabular}{|c|c|c|c|c|c|}
\hline & appearance & & & & acceptability \\
\hline $\mathrm{T}_{0}$ & 8.19 & 7.74 & 7.67 & 7.83 & 7.80 \\
\hline $\mathrm{T}_{1}$ & 7.51 & 7.62 & 7.73 & 7.66 & 7.67 \\
\hline $\mathbf{T}_{\mathbf{2}}$ & $\mathbf{7 . 5 4}$ & $\mathbf{7 . 7 6}$ & $\mathbf{8 . 1 3}$ & $\mathbf{7 . 8 8}$ & $\mathbf{7 . 8 2}$ \\
\hline $\mathrm{T}_{3}$ & 6.65 & 6.65 & 6.84 & 6.57 & 6.67 \\
\hline $\mathrm{T}_{4}$ & 6.31 & 6.21 & 6.51 & 6.24 & 6.14 \\
\hline $\mathrm{T}_{5}$ & 5.60 & 5.50 & 6.09 & 5.69 & 5.67 \\
\hline $\mathrm{SE} \pm$ & 0.120 & 0.098 & 0.087 & 0.072 & 0.059 \\
\hline $\mathrm{CD} @ 5 \%$ & 0.358 & 0.293 & 0.259 & 0.213 & 0.174 \\
\hline
\end{tabular}

* as suggested in Table 1.

\section{CONCLUSION}

Nutritional analysis revealed that the increased substitution level of bottle gourd powder up to $7-10 \%$ increased the nutritional content (crude protein, crude fiber and minerals) when compared to control cookies. Bottle gourd powder also provided greater overall acceptability but increased the hardness value of cookies. For the colour properties, the substitution of bottle gourd powder reduced the $\mathrm{L}^{*}$ and $\mathrm{H}$ (hue) value but increased the $\mathrm{a}^{*}$ value. Overall, it can be concluded that the substitution of wheat flour with bottle gourd powder up to $7-10 \%$ into the formulation of cookies enhanced the nutritional value of cookies.

\section{REFERENCE}

[1] Ghule BV, Ghante MH, Yeole PG and Saoji AN (2007). Diuretic activity of Lagenaria siceraria fruit extracts in rats. Indian Journal of Pharmceutical Sciences 69(6): 817-819.

[2] Deshpande JR, Choudhri AA, Mishra MR, Meghre VS, Wadodkar SG and Dorle AK (2008). Beneficial effects of Lagenaria siceraria (Mol.) standley fruit epicarp in animal models. Indian Journal of Experimental Biology 46(4): 234-242.

[3] Shirwaikar A and Sreenivasan KK (1996). Chemical investigation and antihepatotoxic activity of the fruits of Lagenaria siceraria. Ind J Pharm Sci 58(5):197-202.

[4] Enslin PR, Holzapfel CW, Barbara NK and Rehman S (1967). Bitter principles of the Cucurbitaceae. Part XV. Cucurbitacins from a hybrid of Lagenaria siceraria. J. Chem. Soc. C, 964-972

[5] Chen CH, Chen HW and Chang CY (2008). Friedooleanane- Type Triterpenoids from Lagenaria siceraria and Their Cytotoxic Activity, Chem. Pharm. Bull 56(3): 385-388.

[6] Gangwal A, Parmar SK and Sheth NR (2009). Isolation and immunomodulatory activity of phytocenstituents of Lagenaria siceraria. Pharm Communique (Suppl) 2(2): 46-50. 
[7] Ahmad I, Irshad M and Rizvi MMA (2011). Nutritional and medicinal potential of Lagenaria siceraria. International Journal of Vegetable Science, 17(2): 157-170.

[8] Mohale DS, Dewani AP, Saoji AN and Khadse CD (2008). Antihyperlipidemic activity of isolated constituents from the fruits of Lagenaria siceraria in albino rats. International Journal of Green Pharmacy 2(2): 104-107.

[9] Sindhuja A, Sudha ML and Rahim A (2005). Effect of incorporation of amaranth flour on the quality of cookies. Eur Food Res Technol 221: 597-601.

[10] Hai-Jung Chung (2007). Quality Attributes of Cookies Prepared with Tomato Powder. J Food Sci Nutr 12:229-233.

[11] De Ruiter D (1978). Composite flours. In D. De Ruiter (Ed.), Advances in cereal science and technology (pp. 349-381).

[12] AACC (2000). Approved Methods of the American Association of Cereal Chemists. 9th ed. St. Paul, MN.

[13] Amerine MA, Pangborn RM and Rosseler EB (1965). Principle of sensory evaluation of food. Academic Press New York. pp: 350-376.

[14] Jacob J and Leelavathi K (2006). Effect of fat-type on cookie dough and cookie quality. Journal of Food Engineering 79: 299-305.

[15] Nezhad MH and Butler F (2009). Effect of flour type and dough rheological properties on cookie spread measured dynamically during baking. Journal of Cereal Science 49: 178183.

[16] AOAC (2000). Official Methods of Analysis. 17 $7^{\text {th }}$ edn. Association of Official Analytical Chemists, Gaithersburg, MD, USA.

[17] Mudambi R and Sumati RS (1989) Food Science. New Delhi Wiley Eastern Ltd.

[18] Panse VS and Sukhatme PV (1967). Statistical Methods for Agricultural Workers I.C.A.R. New Delhi. pp: 70-72.

[19] Rosell CM, Rojas JC, Benedito DB, Nobhan GP and Truswell ASC (2001). Influence of hydrocolloids on dough rheology and bread quality. Food Hydrocolloids 15:75-81.

[20] Uthumporn U, Woo WL, Tajul AY and Fazilah A (2015). Physico-chemical and nutritional evaluation of cookies with different levels of eggplant flour substitution. Journal of Food 13 (2): 220-226.

[21] Jenkins DJ, Kendall CW, Marchie A, Faulkner DA, Wong JM, De Souza R and Connelly PW (2003). Effects of a dietary portfolio of cholesterol-lowering foods vs lovastatin on serum lipids and reactive protein. JAMA 290: 502-510. 
[22] Piazza L and Masi P (1997). Development of crispness in cookies during baking in an industrial oven. Cereal Chemistry 74:135- 140.

[23] Arora A and Camire ME (1994). Performance of potato peels in muffins and cookies. Journal of Food Research International 27: 15-22.

[24] Noda Y, Kneyuki T, Igarashi K, Mori A and Packer L (2000). Antioxidant activity of nasunin, an anthocyanin in eggplant peels. Toxicology 148:119-123.

[25] Chung KM and Kwon CS (1999). Properties of cookies added of flour and chinese yam powder. Food Sci Biotechnol 8: 341-343.

[26] Lee JY, Ju JC, Park HJ, Heu ES, Choi SY and Shin JH (2006). Quality characteristics of cookies with bamboo leaves powder. Korean J Food \& Nutr 19: 1-7.

[27] Cho HS, Park BH, Kim KH and Kim HA (2006). Antioxidative effect and quality characteristics of cookies made with sea tangle powder. Korean J Food Culture 21: 541549.

[28] Fimney KF, Morris VH, Yamazaki WT (1950). Micro versus macro cookie baking procedures for evaluating the cookie quality of wheat varieties. Cereal Chem 27: 42-49.

[29] Vratanina DL and Zabik ME (1978). Dietary fiber sources for baked products: Bran in sugar-snap cookies. Journal of Food Science 43:1590-1594.

[30] Purlis E and Salvadori VO (2007). Bread browning kinetics during baking. Journal of Food Engineering 80:1107-1115.

[31] Borrelli RC, Mennella C, Barba F, Russo M, Russo GL, Krome K and Fogliano V (2003). Characterization of coloured compounds obtained by enzymatic extraction of bakery products. Food and Chemical Toxicology 41:1367-1374. 